IP Periodica Polytechnica Civil Engineering

59(2), pp. 95, 102,2015

DOI: $10.3311 /$ PPci.7348

Creative Commons Attribution (1)

RESEARCH ARTICLE
Engineering Properties of

\section{Self-Compacting Concrete Produced by Polypropylene and Steel Fiber}

\author{
Mehmet Karatas, Abdulkadir Gunes
}

Received 23-02-2014, revised 14-07-2014, accepted 11-12-2014

\begin{abstract}
Fresh and hardened properties of self-compacting concrete $(S C C)$, produced by polypropylene and steel fiber, were analysed in this study. Within the scope of the study, natural river aggregate with grain diameter of $15 \mathrm{~mm}$ and a modified polycarboxylate based super plasticizer were used $10 \%$ displaceable with silica fume CEM I 42.5N type cement, on the purpose of supporting the dust content of self-compacting concrete. Polypropylene and steel fiber in different rates were used both separately and together in self-compacting concrete samples and these were compared with fresh and hardened properties of non-fibrous self-compacting concrete. It was deduced from these test results that the fiber use in proper rates would contribute to the engineering properties of self-compacting concrete.
\end{abstract}

\section{Keywords}

Self-compacting concrete $\cdot$ fiber concrete $\cdot$ compressive strength $\cdot$ tensile strength in bending

\section{Mehmet Karatas}

Firat University, Engineering Faculty, Department of Civil Engineering, Elazığ, elazı ̆̆ 23119, Turkey

e-mail: mkaratas@firat.edu.tr

\section{Abdulkadir Gunes}

Ýnönü University, Darende Bekir Ilicak Vocational School, Malatya, 44280, Turkey

e-mail: abdulkadir.gunes@inonu.edu.tr

\section{Introduction}

Concrete is one of the most consumed materials in the world. The number of researches conducted on concrete increase with each passing day and the concrete types with higher Workability, resistance and durability are tried to be manufactured. Selfcompacting concrete (SCC) is a concrete type created as a result of these works. SCC was developed firstly for making permanent reinforced concrete constructions in Japan in 1988. Produced under favour of the new generation super additive agents, SCC prevents decomposition and increases durability by decreasing water permeability also at low water/cementitious material ration [1]. SCC is a high-performance concrete. Its Workability, strength and durability are higher comparing to normal concrete.

With the intent of enhancing the deficient mechanical properties of concrete, some materials may be added into it. And fibers are one of these materials. The aim in producing fiber concretes is enhancing toughness, resistance, against the impact loads, and bending strength of the material. Reinforced homogeneously through fibers with specific properties, fiber concrete is different from conventional concrete with regards to the behaviour and performance it exhibited under different loads, although it resembles to normal concrete at first view. In despite of the random distribution of fibers, the fiber concrete exhibits a homogenous behaviour under load. Strength increase is provided in a new fiber reinforced concrete with the addition of materials that are used as fiber in concrete such as glass, plastic, polypropylene and steel [2].

Fiber reinforced self-compacting concrete (FRSCC) is a specific concrete where the properties of SCC and fiber concrete exist together. Thanks to fibers used, it is possible to prevent crack formation in concrete and to increase ductility and intensity. Fiber concretes are used in bridges, concrete roads, airports, industrial floorings and in slope stabilizations [3]. In this study, it was analysed the fresh and hardened properties of FRSCC, manufactured by using polypropylene and steel fiber. 


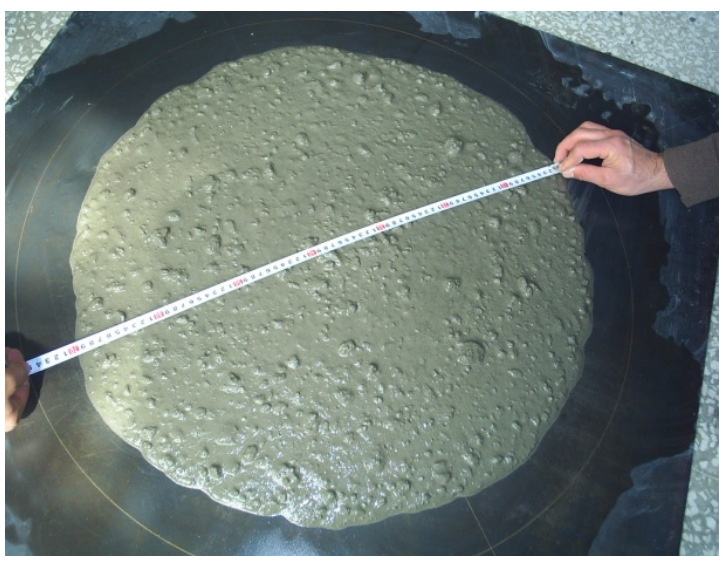

(a)

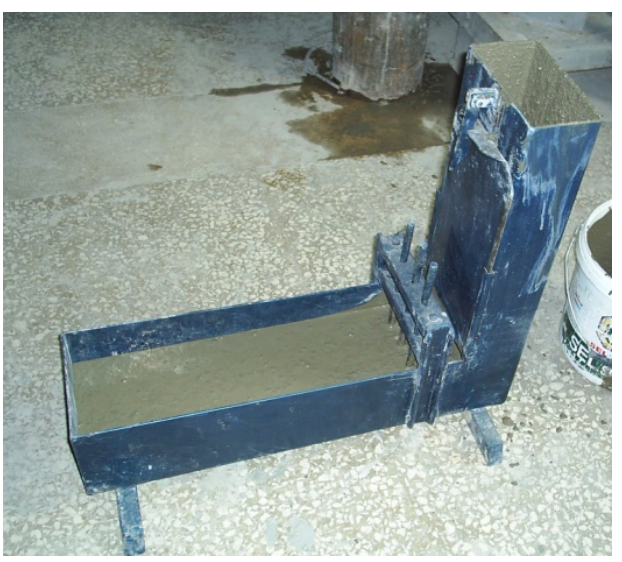

(b)

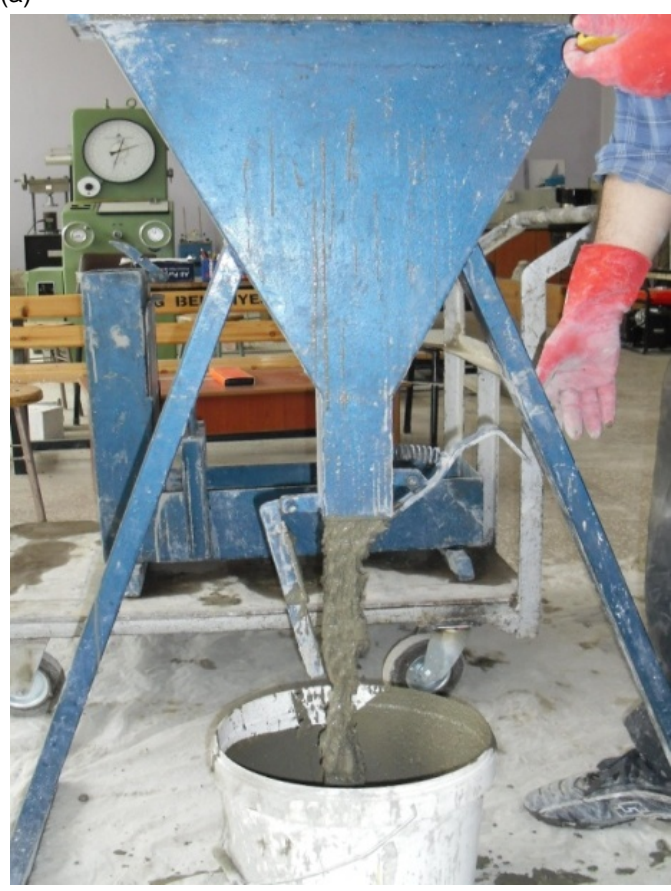

(c)

Fig. 1. (a) Slump flow and $T_{500}$ (b) L-box (c) V-funnel tests for SCC and FRSCC

\section{Experimental study}

\subsection{Materials}

Chemical compounds and physical properties of the materials used in experimental study are given in this chapter. CEM I 42.5N type Portland Cement (PC), conformant to TS EN 197-1 [4], was used as cementitious material in this study. In addition to, silica fume (SF), produced from Eti Electro Metallurgy A. Ş., was added to the mixture as mineral additive, substituted at a rate of $10 \%$ of the cementitious material amount, for contributing the fine dust material quantity $(<0.125 \mathrm{~mm})$ in SCC. The chemical compound and physical properties of the used PC and SF were given in Table 1

The aggregates were provided from Elazig Murat River. The aggregates used had diameters of $0-7,7-15 \mathrm{~mm}$. The specific weight and the water absorption capacity of the aggregates were determined in accordance with TS EN 1097-6 [5] standard. The saturated surface specific gravities of aggregates were taken respectively as 2.63 and 2.64 in the mixture calculations. The fine
Tab. 1. Chemical compound and physical properties for $\mathrm{PC}$ and $\mathrm{SF}$

\begin{tabular}{|c|c|c|}
\hline Component & PC & SF (\%) \\
\hline $\mathrm{SiO}_{2}(\%)$ & 20.2 & 91 \\
\hline $\mathrm{Al}_{2} \mathrm{O}_{3}(\%)$ & 5.8 & 0.58 \\
\hline $\mathrm{Fe}_{2} \mathrm{O}_{3}(\%)$ & 3.23 & 0.24 \\
\hline $\mathrm{CaO}(\%)$ & 64.1 & 0.71 \\
\hline $\mathrm{MgO}(\%)$ & - & 0.33 \\
\hline $\mathrm{SO}_{3}(\%)$ & 2.66 & - \\
\hline Chloride $\left(\mathrm{Cl}^{-}\right)(\%)$ & 0.006 & - \\
\hline LOI (\%) & 2.58 & 1.84 \\
\hline Specific gravity $\left(\mathrm{g} / \mathrm{cm}^{3}\right)$ & 3.1 & 2.2 \\
\hline Specific surface area $\left(\mathrm{cm}^{2} / \mathrm{g}\right)$ & 3484 & $96.5 \%<45 \mu \mathrm{m}$ \\
\hline
\end{tabular}


material quantities of aggregates were calculated respectively as $2.48 \%$ and $0.21 \%$ and their water absorption quantities as $1.57 \%$ and $1.0 \%$ for the classes of $0-7$ and $7-15$.

Elazig mains water was used in this experimental study. It was determined that the mixing water was suitable for use with regards to its chemical composition and $\mathrm{pH}$ value. Modified polycarboxylate based super plasticizer (SP) Viscocrete Hi-Tech 36 , with the intensity of $1.06 \mathrm{~g} / \mathrm{cm}^{3}$, which was procured from Sika Company, was used as chemical additive.

DramixRC 65/60 BN with $0.9 \mathrm{~mm}$ diameter and $60 \mathrm{~mm}$ length steel fiber and Duomix polypropylene fiber (Duomix F20/5.1) were used in the experimental studies, carried out. Technical specifications of fibers were given in Table 2

Tab. 2. Properties of the fibers used

\begin{tabular}{ccc}
\hline Properties of fibers & Steel & Polypropylene \\
\hline Fiber length $(\mathrm{mm})$ & 60 & 20 \\
Fiber diameter $(\mathrm{mm})$ & 0.90 & 0.05 \\
Aspect ratio $(\mathrm{l} / \mathrm{d})$ & 65 & 400 \\
Specific gravity $\left(\mathrm{g} / \mathrm{cm}^{3}\right)$ & 7.8 & 0.90 \\
Tensile strength $(\mathrm{MPa})$ & 1160 & $552-759$ \\
Elastic Modulus $\left(10^{3} \times \mathrm{MPa}\right)$ & 200 & 3.5 \\
Ultimate tensile rate $(\%)$ & $0.5-3.5$ & 25 \\
\hline
\end{tabular}

\subsection{Testing Procedure}

SCC and FRSCC mixing proportions were determined by grounding on EFNARC [6] together with trial tests. Slumpflow, $T_{500}$, L-box and V-funnel (Fig. 1) values of Workability tests for SCC and FRSCC mixtures were obtained by calibrating $\mathrm{SF}$ amounts in the mixtures.

Water-cementitious material ratio was taken as 0.43 and the amount of cementitious material was taken as $500 \mathrm{~kg} / \mathrm{m}^{3}$ for all mixtures. The prepared mixtures were named according to the fiber ratio they contained and the information relating to the materials to be put in $1 \mathrm{~m}^{3}$ mixture was given in Table 3

Firstly, the fresh concrete tests of the mixtures prepared were conducted. After making the fresh concrete tests, hardened concrete tests were made on 81 samples in total, by receiving 3 cubes of $150 \mathrm{~mm}, 3$ prisms of $100 \times 100 \times 350 \mathrm{~mm}$ and 3 cubes of $100 \mathrm{~mm}$. It was made ultrasonic pulse velocity and compressive tests on $150 \mathrm{~mm}$ cube samples, three-point flexural test on $100 \times 100 \times 350$ prism samples and capillary water absorption test on $100 \mathrm{~mm}$ cube samples.

Compressive tests were performed in $7^{\text {th }}, 28^{\text {th }}$ and $91^{\text {st }}$ days for specifying the time-dependent resistance change of the samples. The compressive test was performed by using a 300 tons compressive tester in accordance with TS EN 12390-3 [7, 8] (Fig. 2). For the resistance developments that the samples will show in time, 7, 28, 91 days of the compressive strengths and ultrasonic pulse velocities, sternly to ASTM C597 [9] standard, were measured.

The test for bending strength of concrete was performed through three-points bending test on $100 \times 100 \times 350 \mathrm{~mm}$ of

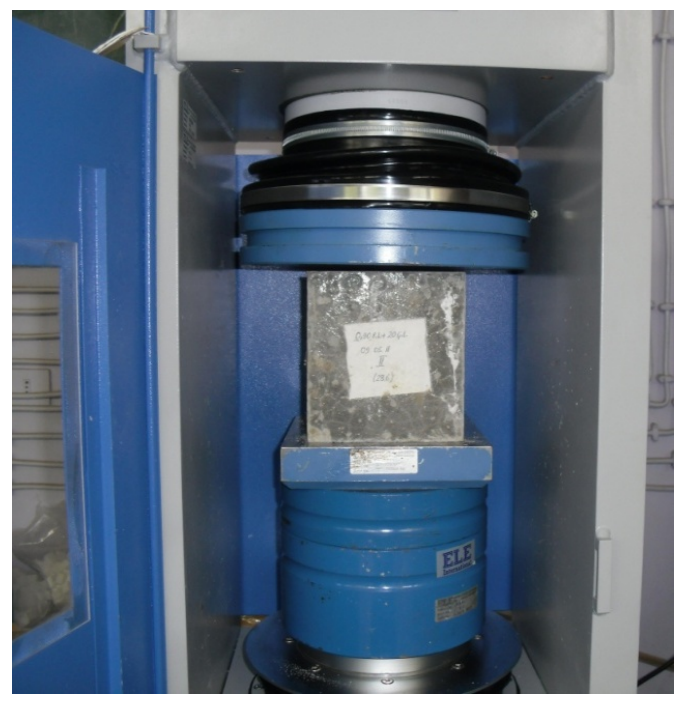

Fig. 2. Concrete compressive strength test

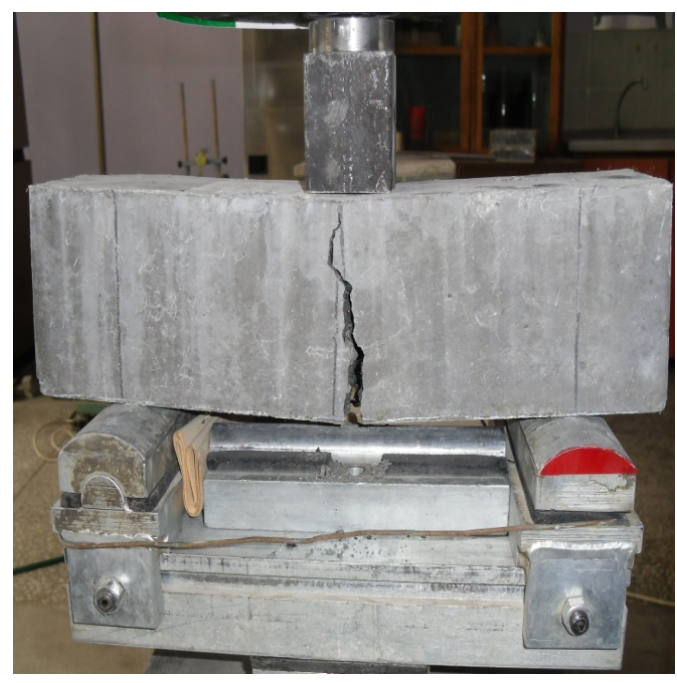

Fig. 3. Three-points bending test

beam samples in accordance with TS EN 12390-5 (2002) [10] and TS 10515 (1992) [11] standards. For the resistance developments that the samples will show in time, 7, 28, 91 days of the compressive strengths were measured (Fig. 3.

$100 \mathrm{~mm}$ sized three cube samples prepared for each mixture were waited in drying oven with $105^{\circ} \mathrm{C} \pm 5$ air circulation until they come to a constant weight, before the capillary absorption test. The samples were covered with paraffin as in Fig. 4 for preventing the evaporation of water during the test. Then the samples were places in the water in a way sinking $5 \mathrm{~mm}$ and free water on the samples was wiped through a damp cloth in periods of 5, 10, 30, 60, 240 and 1440 minutes. The samples were weighed through a $0.01 \mathrm{~g}$ sensitive weigher and the mass raises were determined. The weigh changes were calculated according to the initial weighs of the samples, so the capillary absorption values were found. Capillary absorption test was performed on 28 days of samples in accordance with TS 4045 (1984) [12] standard. 
Tab. 3. $1 \mathrm{~m}^{3}$ concrete mixture amount $\left(\mathrm{kg} / \mathrm{m}^{3}\right)$

\begin{tabular}{|c|c|c|c|c|c|c|c|c|c|}
\hline $\begin{array}{l}\text { Mixtures } \\
\text { Number }\end{array}$ & Control & PF0.45 & PF0.90 & PF1.80 & SF20 & SF40 & SF60 & $\begin{array}{c}\text { PF0.45 + } \\
\text { SF40 }\end{array}$ & $\begin{array}{c}\text { PF0.90 + } \\
\text { SF20 }\end{array}$ \\
\hline$w / c m$ & 0.43 & 0.43 & 0.43 & 0.43 & 0.43 & 0.43 & 0.43 & 0.43 & 0.43 \\
\hline $\begin{array}{l}\text { Cementitious } \\
\text { materials }\end{array}$ & 500 & 500 & 500 & 500 & 500 & 500 & 500 & 500 & 500 \\
\hline Cement & 450 & 450 & 450 & 450 & 450 & 450 & 450 & 450 & 450 \\
\hline Silica fume & 50 & 50 & 50 & 50 & 50 & 50 & 50 & 50 & 50 \\
\hline 1. & & & & & & & & & \\
\hline $\begin{array}{l}\text { Aggregate } \\
(0-7 \mathrm{~mm})\end{array}$ & 1029 & 1025 & 1021 & 1018 & 1022 & 1015 & 1006 & 1011 & 1017 \\
\hline 2. & & & & & & & & & \\
\hline $\begin{array}{l}\text { Aggregate } \\
(7-15 \mathrm{~mm})\end{array}$ & 500 & 500 & 500 & 500 & 500 & 500 & 500 & 500 & 500 \\
\hline $\begin{array}{c}\text { super } \\
\text { plasticizer }\end{array}$ & 7.0 & 8.0 & 9.0 & 9.0 & 7.0 & 7.0 & 8.0 & 8.0 & 8.0 \\
\hline $\begin{array}{l}\text { polypropylene } \\
\text { fiber }\end{array}$ & - & 0.45 & 0.90 & 1.80 & - & - & - & 0.45 & 0.90 \\
\hline steel fiber & - & - & - & - & 20 & 40 & 60 & 40 & 20 \\
\hline $\begin{array}{l}\gamma_{\text {concrete }} \\
\left(\mathrm{kg} / \mathrm{dm}^{3}\right)\end{array}$ & 2.271 & 2.269 & 2.266 & 2.263 & 2.284 & 2.297 & 2.309 & 2.295 & 2.281 \\
\hline
\end{tabular}

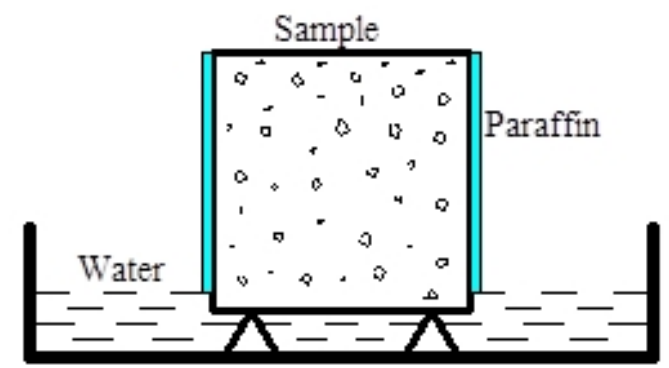

Fig. 4. Capillary absorbtion test

\section{Test results and discussion}

The results of the tests performed on non-fibrous, polypropylene and steel fiber reinforced SCCs were presented in this chapter.

\subsection{Workability tests}

For a concrete to be accepted as SCC, its dispersion, obtained through a test in Abrams' Cone, should be between 550 and $850 \mathrm{~mm}$ [6]. As for EFNARC, this dispersion should be between 650 and $800 \mathrm{~mm}$. The results obtained from fresh concrete tests were given in Table 4 Slump flow state of FRSCC is seen on Fig. 5

When Table 4 and Fig. 5 are analysed, it is determined that as the polypropylene fiber amount increases, the flow diameter of SCC decreases. Using polypropylene fiber in a very small quantity comparing to the concrete volume causes a considerable decrease in slump flow value. Whereas, this occurred in higher amounts of concrete volumes of steel fiber reinforced self compacting concretes. So, it is understood that the steel wires have a commanding lead over. In this study, this is explained depending upon the slenderness of fiber. More water is needed for wetting such fibers comparing to the steel fiber proportion- ately to their slenderness and the balance in mixing water may be corrupted. Concretes, produced according to the results of the flow test results, may be accepted as FRSCC, however other Workability tests may be performed by taking outfit and mould shape during cast-in-place into consideration.

As the fiber rate increases, it is seen that the flow time increases generally for all samples. As the reason for this, it is thought that fibers increased the friction between concrete and testing apparatus. When flow times are analysed, it is seen that the fiber use more than $1.8 \mathrm{~kg} / \mathrm{m}^{3}$ for polypropylene fiber reinforced SCC and more than $40 \mathrm{~kg} / \mathrm{m}^{3}$ for steel fiber reinforced SCC decreased the Workability of mixtures significantly. When increasing the used SA amount between the limiting values, it was seen that the polypropylene fiber reinforced mixtures had flowed through $\mathrm{V}$ funnel without any blockage, but as for the steel fiber reinforced concrete, even the SA was increased, blockage occurred in $\mathrm{V}$ funnel above $40 \mathrm{~kg} / \mathrm{m}^{3}$ and so, it was determined that it caused a decreasing in self-compacting property of concrete (Table 4).

When analysed $\mathrm{H}_{2} / \mathrm{H}_{1}$ height ratios obtained in the result of L box test in Table 4 , it is seen that it was reached to the expected results only in SCC without steel fiber and in SCC with little polypropylene fiber ratio. For all the steel fiber reinforced concretes produced, sufficient results could not be obtained to have opinion about their fluidity properties and transition capability among nets For samples with steel fiber, it was seen that the reinforced transition zone of $\mathrm{L}$ box was blocked because of the steel fibers in concrete, and therefore the test was not concluded (Fig. 6). Accordingly, it is understood that use of steel fiber reinforced concrete to be used in tight reinforced areas could be disadvantageous. 
Tab. 4. Fresh concrete properties of SCC and FRSCC

\begin{tabular}{|c|c|c|c|c|c|c|c|c|c|}
\hline SCC tests & Control & PF0.45 & PF0.90 & PF1.80 & SF20 & SF40 & SF60 & $\begin{array}{c}\text { PF0.45 + } \\
\text { SF40 }\end{array}$ & $\begin{array}{c}\text { PF0.90 + } \\
\text { SF20 }\end{array}$ \\
\hline \multicolumn{10}{|l|}{ Slump- } \\
\hline $\begin{array}{l}\text { flow } \\
(\mathrm{mm})\end{array}$ & 750 & 770 & 730 & 610 & 750 & 740 & 690 & 750 & 710 \\
\hline $\mathbf{T}_{500}(\mathrm{~s})$ & 2 & 4 & 6 & 8 & 3 & 4 & 5 & 3 & 4 \\
\hline $\begin{array}{l}\text { L-box; } \\
\left(\mathrm{H}_{2} / \mathrm{H}_{1}\right)\end{array}$ & 0.890 & 0.860 & 0.820 & 0.740 & 0.710 & - & - & - & 0.830 \\
\hline $\begin{array}{c}\text { V-funnel } \\
\text { (s) }\end{array}$ & 4 & 6 & 8 & 9 & 5 & 6 & - & 5 & 6 \\
\hline
\end{tabular}

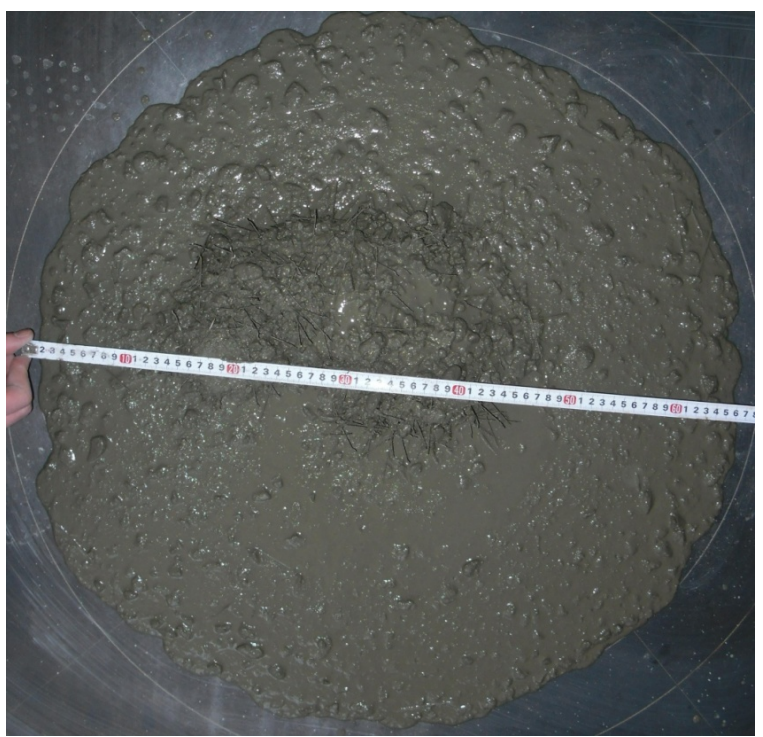

Fig. 5. Slump flow state of FRSCCs

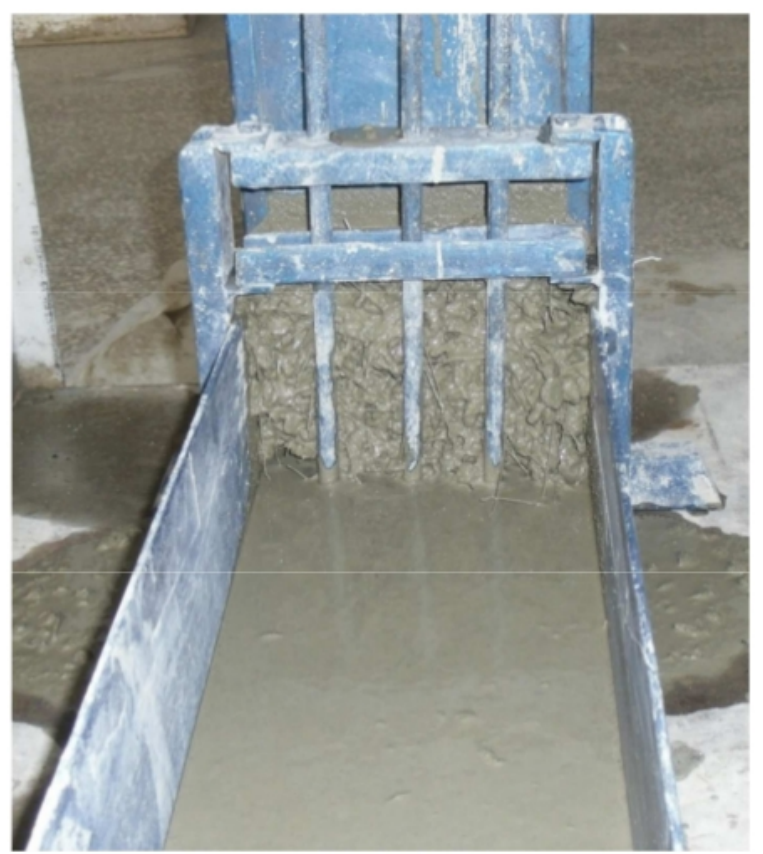

Fig. 6. Steel fiber reinforced SCC to induce blockage during the L box test

\subsection{Hardened concrete tests}

Cube samples of $150 \mathrm{~mm}$ were subjected to compressive strength test. The time dependent resistances of the samples were measured on $7^{\text {th }}, 28^{\text {th }}$ and $91^{\text {st }}$ days. The control and time dependent compressive strengths of FRSCCs that takes place in the scope of the research were presented in Fig. 7. When Fig. 7 is analysed; it is seen that 0.45 and $0.90 \mathrm{~kg} / \mathrm{m}^{3}$ of polypropylene fiber additive created a slight increase in compressive strengths of 7 days cubes reinforced with polypropylene comparing to the control concrete, however later on, that $0.45 \mathrm{~kg} / \mathrm{m}^{3}$ polypropylene additive increased the compressive strength at an insignificant amount. Generally, it was seen that polypropylene fibers did not have an important impact on compressive strength and even, it inclined to decrease the concrete compressive strength with increasing fiber volumes. It is defined that there was a very little decrease in compressive and tensile strength of the samples including polypropylene fiber and this is connected to pores created by the polypropylene fibers [13].

The effect of steel fiber on compressive strengths showed an alteration based on the fiber volume. It can be said that steel fibers did not cause an important increase or decrease in terms of compressive strength. As the steel fiber ratio increases, correspondingly a homogenous mixture cannot be obtained and therefore the defects in concrete may increase. However, as the amount of steel fibers increases, it is seen that concretes behaved ductile during the compressive test and that their energy absorption property increased under compressive

Due to water/cementitious material ratios are equal for all samples; the fiber type and amount do not have a big affect on compressive strength as it is seen in the graphic.

The bending strengths of SCC and FRSCCs were measured for 7, 28 and 91 days and their time-dependent bending strengths were presented in Fig. 8 According to the bending strength results, it was seen that polypropylene fibers did not contribute significantly to bending strengths. In the bending tests, it was seen that the breakings of non-fibrous samples were rapid and early, and as for the fiber reinforced samples, due to concrete gained a ductile structure, it was seen that the breaking became later and the concrete had a ductile fracture property.

When Fig. 8 analysed, it is seen that the more steel fiber ratio increases, the more bending strength. The ultimate bending 


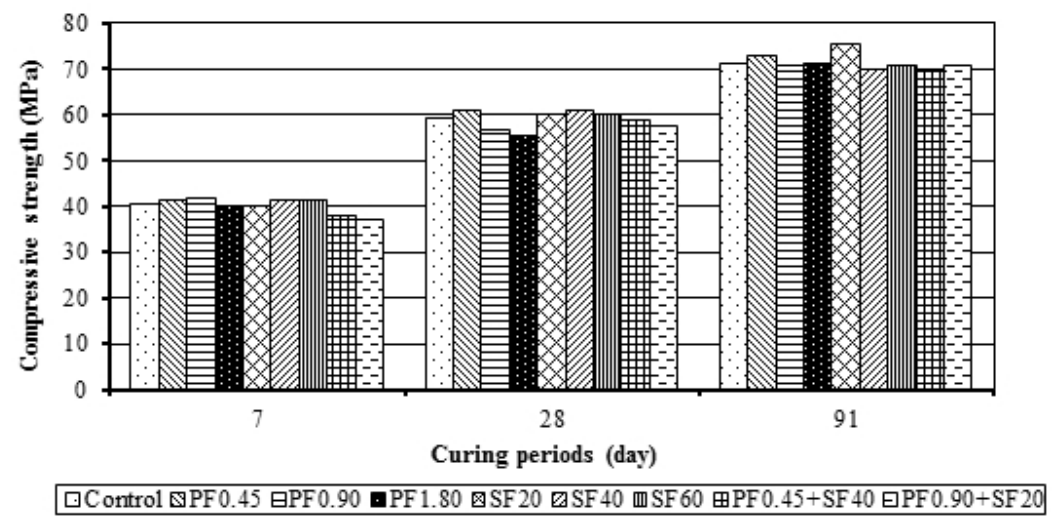

Fig. 7. Compressive strength-curing periods relations of SCC and FRSCCs

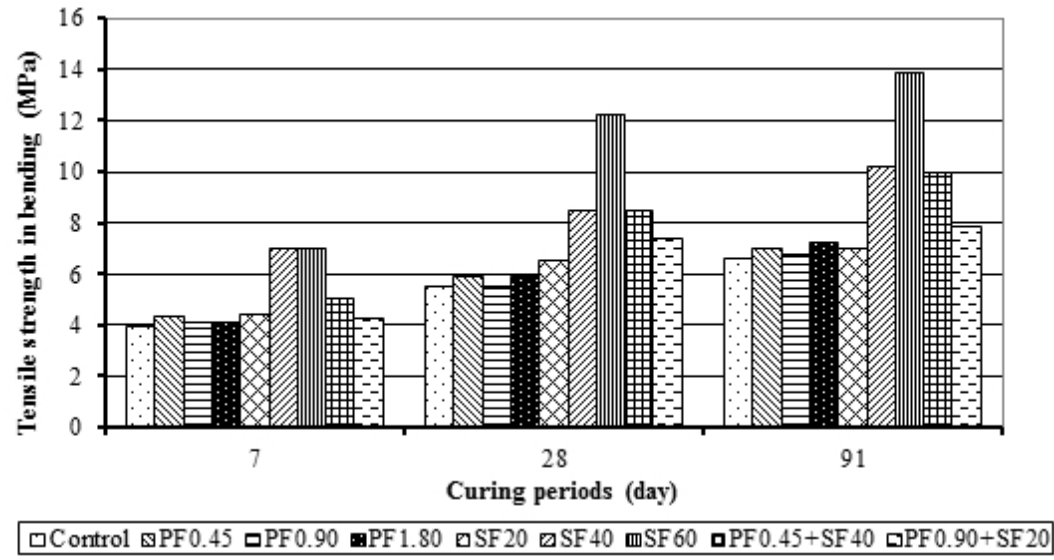

Fig. 8. Tensile strength-curing periods relations of SCC and FRSCCs

strengths of concretes with steel fibers show an increase between 50 - 100\% comparing to normal concretes. This increase results from tensile strengths of steel fibers. After cement paste matrix is fractured (the first fracture) due to fibers make stress transfer and distribution from the ends of the fractures, load increases some more after the first fracture. At that, maximum bending load becomes more than non-fibrous concretes [14]. It is stated that steel fiber reinforced concretes had an important bending performance due to fracture development and the fracture developments in loading state [15, 16]. And Y1ldirım (2002) [17] stated that steel fibers developed their bending strengths excessively because they were longer than other fibers.

Ultrasonic pulse velocity (UPV) tests were performed on cube samples of 7,28 and 91 days and the UPV were given in Table 5 together with the compressive strengths.

When Table 5 is analysed, it is seen that ultrasonic pulse velocities in $7^{\text {th }}, 28^{\text {th }}$ and $91^{\text {st }}$ days were close to each other. As the case for compressive and bending strengths of concretes, it was seen that polypropylene fiber additives did not change ultrasonic pulse velocities much. According to the measurement values, it is seen that the polypropylene fiber and the increasing fiber amount do not have an effect on the ultrasonic pulse velocity. A direct relation was not seen between ultrasonic pulse velocity and compressive and bending strengths for steel fiber reinforced concretes.

Tabak (2004) [18] stated that, on the contrary to expectations, 28 days of ultrasonic velocities of steel fiber reinforced concretes were obtained at lower values comparing to the control concrete, and that this decrease became fast as the fiber volume and the aspect ratio increased. And as the reason for this, he showed very small sized pores to be available arising from emplacement at the transition zones of fibers touching to concrete and fibers to have a random distribution. And Yildırım (1994) [19] stated that the use of steel fiber did not change the ultrasonic velocities of concretes.

Capillary water absorption test was realized in accordance with TS 4045 (1984) [12] standard. Capillary absorption coefficients of concrete mixtures were presented in Fig. 9. When Fig. 9 is analysed, it is seen that polypropylene fibers did not have an important effect on capillary absorption coefficients of SCC. While capillary absorption coefficient of SCC with $0.45 \mathrm{~kg} / \mathrm{m}^{3}$ polypropylene fiber was some more than the capillary absorption coefficient of non-fibrous SCC, as the polypropylene fiber ratio increased it approached to capillary absorption coefficient of non-fibrous SCC. It is seen that the capillary absorption coefficients of steel fiber reinforced SCC are 
Tab. 5. Cube compressive strengths and UPV of SCC and FRSCCs for 7, 28 and 91 days

\begin{tabular}{|c|c|c|c|c|c|c|}
\hline \multirow{2}{*}{ Mixtures Number } & \multicolumn{2}{|c|}{7 days } & \multicolumn{2}{|c|}{28 days } & \multicolumn{2}{|c|}{91 days } \\
\hline & $\begin{array}{c}\text { Compressive } \\
\text { strength (MPa) }\end{array}$ & UPV (km/sn) & $\begin{array}{c}\text { Compressive } \\
\text { strength (MPa) }\end{array}$ & UPV (km/sn) & $\begin{array}{c}\text { Compressive } \\
\text { strength (MPa) } \\
(\mathrm{MPa})\end{array}$ & UPV $(\mathrm{km} / \mathrm{sn})$ \\
\hline Conrol & 40.37 & 4.54 & 59.44 & 4.65 & 71.45 & 4.71 \\
\hline PF0.45 & 41.40 & 4.51 & 60.86 & 4.64 & 73.04 & 4.69 \\
\hline PF0.90 & 41.77 & 4.51 & 59.82 & 4.63 & 71.04 & 4.71 \\
\hline PF1.80 & 40.30 & 4.47 & 55.52 & 4.65 & 71.14 & 4.71 \\
\hline SF20 & 40.17 & 4.50 & 60.00 & 4.63 & 75.42 & 4.68 \\
\hline SF40 & 41.47 & 4.49 & 60.97 & 4.63 & 70.15 & 4.69 \\
\hline SF60 & 41.37 & 4.49 & 60.15 & 4.65 & 70.84 & 4.70 \\
\hline PF0.45 + SF40 & 37.97 & 4.50 & 58.91 & 4.62 & 69.39 & 4.68 \\
\hline PF0.90 + SF20 & 37.10 & 4.48 & 57.51 & 4.61 & 70.67 & 4.69 \\
\hline
\end{tabular}

very low. It is thought that the most important reason for that is the spaces constituted by steel fibers to be filled by SF due to its fine structure, so the formation of a spaceless structure.

\section{Conclusions}

In this study, a research has been conducted on fresh and hardened concrete by adding polypropylene fiber, steel fiber and polypropylene fiber + steel fiber into self-compacting concrete, and it was came to the conclusions below by researching the effects of fiber on self-compacting concrete.

- In the experimental study, it was seen that the Workability could be maintained by increasing the additive amount within proper limits in case that propylene fiber was used at an amount of $1.8 \mathrm{~kg} / \mathrm{m}^{3}$ and steel fiber was used at an amount of $60 \mathrm{~kg} / \mathrm{m}^{3}$, and that the Workability was corrupted in case of using fibers more than these values.

- Pouring fiber concretes requires a better planning and labour comparing to non-fibrous concrete. The behaviour of hardened FRSCC is depended substantially on its Workability and, accordingly, being able to be placed into mould spacelessly. Self-compaction not to be obtained adequately may cause great disadvantages with regards to resistance and durability of fiber reinforced composite.

- It was not seen a significant effect of polypropylene and steel fibers, added to the mixture, on the ultrasonic pulse velocity of SCC.

- It was determined that the polypropylene fibers added to the mixture did not have a significant effect on the compressive strength of SCC, and additionally, as the propylene fiber amount in the mixture increased, the compressive strength of SCC inclined to decrease.

- The effect of steel fiber on the compressive strength of concretes showed alteration based on the fiber volume. It can be said that the steel fibers added to the mixture did not cause an important increase or decrease in compressive strength of SCC. As the amount of steel fibers increased, it was seen that concretes behaved more ductile during the compressive test and their energy absorption properties increased under compressive

- It can be said that the polypropylene fiber + steel fiber added to the mixture did not cause an important increase or decrease in compressive strength of SCC.

- It was determined that the polypropylene fibers added to the mixture did not affect much to the bending strength of SCC.

- It is determined that the steel fibers added to the mixture increased the compressive strength of SCC. The ultimate bending strength of steel fiber reinforced SCC shows an increase between 50 - 100\% comparing to normal concretes. Besides, it was determined that as the steel fiber amount increases in the mixture, the bending strength of SCC increased significantly.

- It was determined that polypropylene fiber + steel fiber added to the mixture increased the bending strength of SCC comparing to the control concrete. The steel fiber in mixed mixtures effects significantly to the bending strength of SCC.

- It was seen that non-fibrous samples showed instantaneous fracture and the samples with fibers were broken more lately and ductile.

- It was seen that polypropylene fibers did not have an important affect on capillary absorption coefficient of SCCs. The increasing polypropylene fiber amount decreased capillary absorption coefficient and approximated the capillary coefficient of non-fibrous concrete (control concrete).

- It was seen that the capillary absorption coefficients of steel fiber reinforced SCC was rather low. It was determined that this coefficient decreased by the increase of steel fiber amount.

- In mixtures, where the fibers were used together, the capillary coefficient was lower that the control concrete. The steel fiber amount to increase and polypropylene fiber amount to decrease in this mixture decreased the capillary coefficient. 


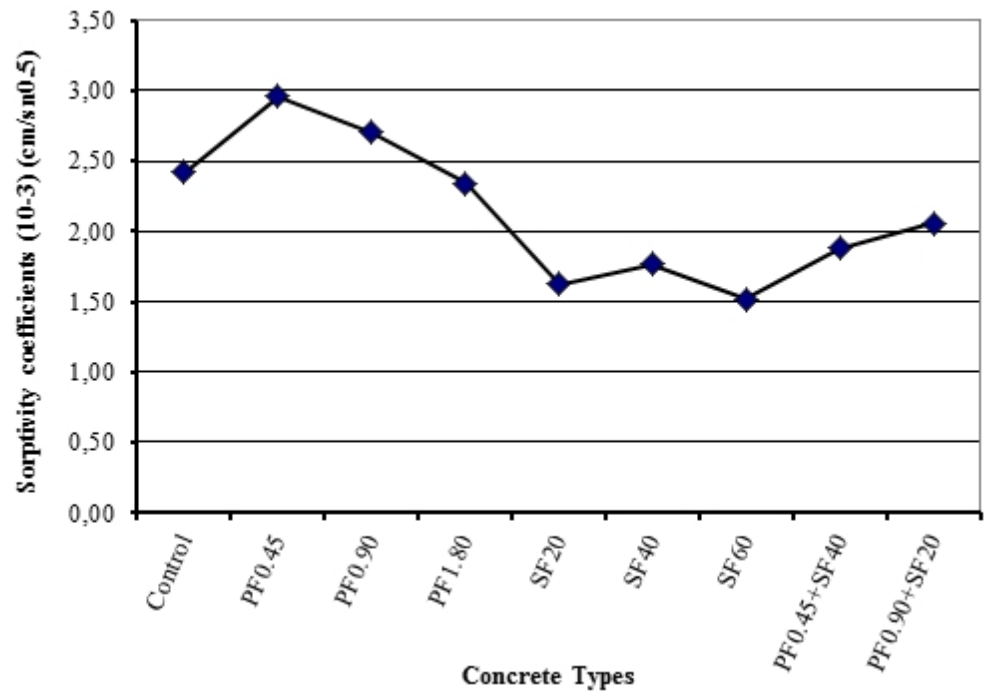

Fig. 9. Sorptivity coefficients of SCC and FRSCCs

\section{References}

1 Okamura H, Ouchi M, Self Compacting Conrete Development, Present and Future, In: Å. Skarendahl, Ö. Petersson (eds.), Proceeding of 1st International Rilem Symposium on Self Compacting Concrete; Stockholm, Sweden, 1999, p. 804. e-ISBN: 2912143721.

2 Şimşek O, Beton ve Beton Teknolojisi (in Turkish), Seçkin Yayıncılık, (2009).

3 Balık F, Kamanlı M, Beton Teknolojisi (in Turkish), Nobel Basımevi, (2003).

4 TS EN 197-1, Genel Çimentolar-Bölüm 1: Genel Çimentolar - Bileşim, Özellikler ve Uygunluk Kriterleri (in Turkish), Türk Standartları Enstitüsü; Ankara, 2002.

5 TS EN 1097-6, Agregaların Mekanik ve Fiziksel Özellikleri için Deneyler Bölüm 6: Tane Yoğunluğu ve Su Emme Oranının Tayini (in Turkish), Türk Standartları Enstitüsü; Ankara, 2007.

6 The European Guidelines for Self Compacting Concrete Specificiation, Production and Use, Self-Compacting Concrete European Project Group, 2005, WwW.efnarc.org

7 TS EN 12390-4, Beton-Sertleşmiş Beton Deneyleri-Bölüm 4: Basınç Dayanımı-Deney Makinelerinin Özellikleri (in Turkish), Türk Standartları Enstitüsü; Ankara, 2002.

8 TS EN 12390-3, Beton-Sertleşmiş Beton Deneyleri-Bölüm 3: Deney Numunelerinde Basınç Dayanımının Tayini (in Turkish), Türk Standartları Enstitüsü; Ankara, 2003.

9 ASTM C 597, Standard Test Method for Pulse Velocity Through Concrete, 2003.

10 TS EN 12390-5, Beton-Sertleşmiş Beton Deneyleri-Bölüm 5: Deney Numunelerinin Eğilme Dayanımının Tayini (in Turkish), Türk Standartları Enstitüsü; Ankara, 2002.

11 TS 10515, Beton-Çelik Tel Takviyeli-Eğilme Mukavemeti Deney Metodu (in Turkish), Türk Standartları Enstitüsü; Ankara, 1992.

12 TS 4045, Yapı Malzemelerinde Kılcal Su Emme Tayini (in Turkish), Türk Standartları Enstitüsü; Ankara, 1984.

13 Huang W-H, Improving the Properties of Cement-Fly Ash Grout Using Fiber and Superplasticizer, Cement and Concrete Research, 31, (2001), 10331041.

14 Uğurlu A, Çelik Liflerle Güçlendirilmiş Beton (in Turkish), DSİ Genel Müdürlüğü Teknik Araştırma ve Kalite Dairesi Başkanlığı, (1994). Yayın No: MLZ-878.

15 Look TS, Xiao JR, Flexural Strength Asessment of Steel Fiber Reinforced Concrete, ASCE Journal of Materials in Civil Engineering, 11(3), (1999), 188-196.
16 Bantia N, Fiber Reinforced Concrete: Present and Future, In: Proc.,AsiaPacific Spec. Conf. On the Fiber Reinforced Concrete; CI-Premier Singapore, 1997, pp. 1-10.

17 Yıldırım ST, Lif Takviyeli Betonların Performans Özelliklerinin Araştırılması(in Turkish), Doktora Tezi, Fırat Üniversitesi Fen Bilimleri Enstitüsü; Elazı $\breve{g}, 193 \mathrm{~s}, 2002$.

18 Tabak V, Çelik Lifli Betonda Lif ve Lif Boy/Çap Oranlarının Değişiminin Betonun Mekanik Özelliklerine Etkisi (in Turkish), Dokuz Eylül Üniversitesi Fen Bilimleri Enstitüsü, Yüksek Lisans Tezi; İzmir, 134s, 2004.

19 Yıldırım MA, Hafif ve Yarı Hafif Betonlarda Çelik Lif Kullanımının Etkisi (in Turkish), İstanbul Teknik Üniversitesi Fen Bilimleri Enstitüsü, Yüksek Lisans Tezi; İstanbul, 64s, 1994. 